\title{
The Process of Civilization IN IbN TufaYl's HaYy IbN YaQZaN
}

\author{
Mihajlo Božović
}

Ibn Haldun University, Istanbul, Turkey

\begin{abstract}
Originally written as a philosophical work, Ibn Tufayl's Hayy ibn Yaqzan incorporates in its story many elements that could be regarded as elements of the civilizational process in modern times. In this paper we will analyze these elements of the civilizational process and try to reassemble them into a clear theory of civilization. In order to conduct these analyses, the elements found in the story will be contrasted and perceived through the concepts of civilization found in the works of Ibn Khaldun and Arnold J. Toynbee.

The resulting conclusion will point out many similarities between these authors in conceiving civilizations, especially in the notions of the development of intellect and the unity of humankind. But it will also show us the crucial divergence in the importance and existence of society and its binding elements such as 'asabiyya. Still, Ibn Tufayl's uniqueness and originality will be seen in his tripartite definition of existence and his own take on the goal/s of the civilizational process.
\end{abstract}

Keywords: Ibn Tufayl, Toynbee, Ibn Khaldun, civilization, process, society

\section{Introduction}

"All men by nature desire to know."

This quotation from Aristotle can serve as an appropriate subtitle to the book which dedicates its every page to gaining knowledge. Still, even though Ibn Tufayl (Abū Bakar ibn Ṭufayl) intended to present his book as a guide,

Corresponding author: mihajlobozovic88@gmail.com 
for both the worthy and the unworthy, to obtaining the higher mysteries or to persuading them not to obtain them, as it can be seen in the conclusion of his philosophical novella (Ibn Tufail 1929: 178), in this paper we will try to discern a possible civilizational process that Ibn Tufayl, probably accidentally and unknowingly, implemented in his philosophical work. As the book was not written with the purpose of analyzing the civilizational processes but the acquisition of knowledge needed to ascend to the highest plane of apprehension, it might prove difficult to distinguish between the pure philosophical and the civilizational areas, which may lead us astray and make us delve deeper into the concerns which transgress the limitations of our subject.

The writing of this paper could come across a lot of obstacles and dead-ends, especially because we decided to look for something in a book whose main purpose was not to provide us with the information that we seek, but rather with something completely different. That core knowledge which is focused on philosophy will be discussed only sporadically as it is beyond the purpose of this paper. We will try to use the story of Hayy ibn Yaqzan (Hayy bn Yaqzān) as a valid source of facts that concern the theoretical ideation of Ibn Tufayl regarding the civilizational process. We are aware that it will not always be possible to do so as this is still only a work of fiction, despite its instructional dimension.

Our paper will begin with a brief overview of Ibn Tufayl's life and his book Hayy Ibn Yaqzan because both of them deserve to be mentioned and analyzed with the purpose of providing more context and support to, and shedding more light on, the topic that we intend to take up in the second part of the paper. This second part will encompass all the civilizational elements that could be found in the story of Hayy Ibn Yaqzan and those elements will be contrasted and perceived through the concept of civilization found in the works of Ibn Khaldun (Ibn $\underline{\text { Haldūn}) ~ a n d ~ A r n o l d ~ J . ~ T o y n b e e . ~ T h e ~ t h e o r i e s ~}$ propounded by these two famous and eminent scholars will serve us as the guidelines in our effort to elucidate the meanings of specific elements found in Ibn Tufayl's work. The main objective of this paper is to form, as much as it is possible, a clear civilizational theory based on Hayy ibn Yaqzan. The results of our search will be presented in the concluding part of the work as a summary of the entire process.

\section{Ibn Tufayl and His "Hayy Ibn Yaqzan"}

Born in early $12^{\text {th }}$ century, Ibn Tufayl (d. 1185/6) had an interesting and exciting life that was made such by his environment, it being Muslim Spain or Al-Andalus. Abu Bakar Ibn Tufayl lived in the period marked by the disintegration of the Umayyad caliphate of Cordoba, formation of the Petty 
Kingdoms (Mulūk al-ta 'ifa), and rise of the Barber Muslim dynasties the Almoravides (al-murabitūnn) and the Almohads (al-muwahhhidūn). Actually, Ibn Tufayl gained prominence as a physician and philosopher at the court of Almohad prince, and later sultan, Abu Yaqub Yusuf (Abū Ya'qūb Yūsuf) (r. 1163-84). He exerted a great influence upon the ruler who was a great lover of learning and books. Ibn Tufayl was also credited with introducing Ibn Rushd to the Almohad court and enabling him to work under the protection of the sultan. Ibn Tufayl was trained in medicine, philosophy (in which he followed the teachings of the father of Andalusian philosophy Ibn Bajja (Ibn Bāğğa)), Islamic law and astronomy. Astronomy was a very important subject for Ibn Tufayl as he was one of the key figures in the so-called "Andalusian Revolt" which was raised against the authority of Ptolemaic astronomy (Goodman 2000: 319). We will see, later on, that all of these sciences play a crucial and integral part in the formation of Hayy Ibn Yaqzan as a philosopher. He dedicated his life to writing but the majority of his work has been lost. Ibn Tufayl died in Marrakech, just one year after his patron Abu Yaqub Yusuf, in 1185/6.

Although this brief biography of Ibn Tufayl's may make it appear calm and undisturbed, his whole life was marked by a struggle between the outer and the inner spheres of the Muslim society in the Almohad era. In order to understand this struggle, we must first understand the Almohad dynasty and its principles of rule. Coming from a harsh desert area, the Almohad sect was a response to the previous, competing Barber dynasty of the Almoravides that lost its fervor in contact with the luxurious Al-Andalus. The Almohads, as it is stated in their name which comes from the Arabic Al-muwahhidūn (the Unitarians), believed in a strict spiritual conception of God and literal acceptance of the Quranic teaching. "'Reasoning' said the Mahdi', 'can have no place in the divine Law'" (Fulton 1929: 6). Nevertheless, in the privacy of his chambers, the Caliph, who enforced the strict laws dictated by the Almohad principles, enjoyed the company of free-thinking philosophers. The strict letter of the Quran was beneficial for keeping the spiritual health of the masses and the state's welfare, their duty was not to think but to believe and obey. But the selected few were allowed to practice a way of thinking that transgressed the limitations of the Almohad dogma. This struggle between the literal interpretation and free-thinking can also be observed in the book and it seems that Ibn Tufayl made it a latent topic of his philosophical treatise. Actually, at the end of his book Ibn Tufayl supports this separation, as, according to him, "the mass of mankind have neither the force of intellect to apprehend them [moral rules] clearly as ideas, nor the force of character to follow them strictly as laws" (Ibn Tufail 1929: 163).

1 Muhammad ibn Tumart (Muhammad ibn Tūmart), founder of the Almohad dynasty. 
As previously stated, Hayy Ibn Yaqzan was written as a way to protect the people from lies and foolishness and as a guide for the worthy to obtaining the pure knowledge. The title of the book in translation to English would be Alive, son of Awake, but in the West it is better known by its Latin name Philosophus Autodidactus. The story follows a child who grows up on an isolated Indian island. His sole company are wild beasts, one of which acts as his parent, nurturing him until he is able to take care of himself. The origin of this child brings us to the ambiguity which is set at the very beginning of the story. Is Hayy just an abandoned child who was saved by the providence of God or by mere accident; or was he created on the island by the perfect mixture of the elements and the most balanced Temperature in the World? Either way, he was brought up by a doe, similar to the story of Romulus and Remus, and on his own he started the process of acquiring knowledge from his environment. From the very beginning we can understand the Autodidactus part of the Latinized title of the book, as Hayy employed logic to understand the world he was living in. The notion of pure, unadulterated knowledge that was untainted by traditions is in this way present from the first endeavors of the child Hayy Ibn Yaqzan.

As knowledge, or better yet its acquisition, is the main topic of the narrative, we will briefly discuss it here. By the age of 49 , Hayy was already a fully grown man with a firm grasp of all the knowledge available to human beings. He was able to maintain the Vision (of the other World) and had the knowledge of the Essence as was stated: "He that has the Knowledge of this Essence, has the Essence itself; but I have the Knowledge of this Essence. Ergo, I have the Essence itself" (Ibn Tufail 1929: 143). The acquisition of the knowledge was gradual and it followed a natural upward movement from the knowledge of Nature, Anatomy, and Astronomy, to the knowledge of the World, God and Essence. Of course, this knowledge was not only theoretical, as he first acquired the practical or the technical knowledge in order to advance to the higher one. The death of the doe who acted as a parental substitute pushed Hayy to search for the more elusive knowledge as it can be seen in his search for the cause of Motion, Attributes of Body, Forms, Cause and Effect, Infinity, Creator, etc. By finding the answers to all of these questions he arrived at the presence of God, the unaltered Truth which was to him the sole purpose of living.

Toward the end of the book he encounters for the first time another human being, and that is Absal (or Asal) ${ }^{1}$, a religious man who came to the uninhabited island for the seclusion which would lead him to the Near-

1 In the Ocley's translation it is stated Asal, but in original Arabic text it is clearly stated Absal (see: Aminn 2005). 
ness of God. Absal becomes eager to teach Hayy to speak, hoping to impart knowledge and religion to him. But he finds out that Hayy already knows the Truth and that his religion is full of symbols and representations of the real Truth. Still, Hayy recognizes the truth of Absal's religion and accepts its formal conditions. Meanwhile, as they spend some time together it becomes obvious that Absal is the one who was being taught and Hayy the real teacher. When Absal explains his own society to Hayy, he finds two things incomprehensible. The first thing is the usage of symbols by the prophet that leads the "Mankind to fall into the grave error of conceiving the Truth corporeally" (Ibid: 161). And the second that the prophet allowed the "amassing of wealth and overindulgence in eating, leaving the men idle to [...] neglect the Truth" (Ibid: 162). Hayy decided to follow Absal to his island in order to help the people see the Truth, but he was rejected by the people who followed the letter of the Law blindly and were not capable of seeing through the symbols. Only a selected few were able to comprehend the Truth Hayy was there to present. Concluding that symbols and restrictive laws are the best that a majority of people is capable of receiving, Hayy and Absal returned to their island and continued their devotion until the inevitable overtook them.

Even though, all of the Mankind has the capability of apprehending the real Truth by possessing the Essence that connects us all to God, still Hayy Ibn Yaqzan gave up on the notion that the entire humankind wants do achieve that goal. He leaves them to suffer in their riches and luxuries acknowledging that it is the best thing they can obtain. However, precisely by writing his philosophical piece Ibn Tufayl does not abandon Mankind and he invites everyone who wants or needs to progress to the higher levels of knowledge to follow his hero Hayy Ibn Yaqzan and achieve what is by God's Will given to us.

\section{The Process of Civilization}

It may not be as obvious as the learning process in Hayy Ibn Yaqzan, but the civilizing process can be perceived with some effort. Ibn Tufayl enabled us to consider the civilizing process in its purest form, that is to say, since the birth of a human being. The specificum of this narrative is that it allows us to take into consideration both an already civilized society and an uncivilized one undergoing the process of civilization. However, since we cannot clearly distinguish a complete civilization process as a singular narrative from this story, we will use two existing civilization theories to help us in constructing, or even reconstructing, the civilizational theory of Ibn Tufayl.

The first of the two scholars that will be taken into consideration is Ibn Khaldun. We will find a lot of similarities between Ibn Tufayl's and Ibn 
Khaldun's approaches in the field of knowledge since they both represent continuations of Al-Farabi's (al-fārābī) and Ibn Sina's (ibn sīnā) teachings. So, at the beginning we have a child with an unknown origin and with no identity, who was born in the perfect climate, one better than the forth climate which is considered to be the best by Ibn Khaldun (Ibid: 40-42). This climate is located just beneath the Equinoctial Line and here we see that Ibn Tufayl considered Galen's schematic of climates in an even broader concept than Ibn Khaldun did. Ibn Khaldun's deterministic cyclical theory of civilizations can be perceived in Ibn Tufayl's writings, even though he uses a much more organic conceptualization for his theory. In Hayy Ibn Yaqzan Ibn Tufayl refers to the world as the World of Generation and Corruption ('ālam al-kawn wa al-fasād) (Ibid: 104). According to Ibn Tufayl's philosophy, this created world is the Body and it is prone to generation and corruption that constantly follow each other because the Body is a mixture of opposites. When these elements are not in balance, the Body decays (Ibid: 120). Nevertheless, a complete annihilation cannot be achieved. The world can only be changed as it follows the Divine World that is indestructible (Ibid: 154). One of the aspects of the World's destruction is the same as the notion of civilizational decay present in the works of Ibn Khaldun. Even before getting in touch with the civilized society, Hayy concluded that material things only produce torments, evils and hindrances (Ibid: 116). This opinion is confirmed when he goes to the inhabited island and sees that civilized men are occupied by the thoughts of riches, money and possessions in such a way that they are neglecting their connection with God (Ibid: 117-118). In Ibn Yaqzan's eyes a separation from the real Truth leads to corruption and decay. Those qualities are similar to those seen in Ibn Khaldun's category of sedentary people. When they give way to material objects and luxury, their societies are led to ruin.

The strongest connection we can find between Ibn Tufayl and Ibn Khaldun is in their interpretation of the acquisition of knowledge. After his second year of life, Hayy starts learning and thinking, which transforms into a systematic acquisition of knowledge that eventually develops into learning the final Truth. Both of the scholars start with the acquisition of the most basic knowledge, which Ibn Khaldun terms practical knowledge ('amali) (Alatas 2012: 30), and it develops into Ibn Khaldun's discerning intellect (al'aql al-tamyizì). After the death of his mother-like doe, we discover that Hayy Ibn Yaqzan starts to express feelings which are immediately followed by the development of Ibn Khaldun's experimental intellect (al-aql al-tağrïbì) that will, in turn, help him determine the cause of death of his doe. Similarities can be also seen in the formulations that the heart is the source of human's ability to think. Ibn Tufayl provides us with the complete formation of the 
Heart as the seat of the Spirit that governs the rest of the Body. In his conception the Body is merely a tool, while the Spirit, which is located in the Heart, governs the Body and through the brain controls the senses. The Spirit is also in control of that which Ibn Khaldun calls the speculative intellect (al-'aql al-nazarì) which involves both perceptions and apperceptions (Ibid: 79). Adding to the three intellects of Ibn Khaldun, which Ibn Tufayl calls Senses, Intellectual Speculation and Imagination, he introduces the Essence which is in charge of apprehension of the other World. Here Ibn Tufayl enters the domain of mysticism, toward which Ibn Khaldun had a negative stance. If we look at the knowledge Ibn Yaqzan acquired during his independent research, we will surely find it appropriate to call Hayy ibn Yaqzan Philosophus Autodidactus. He acquired knowledge about Nature, Anatomy, Astronomy, World, God and the Essence. The first three of the sciences are on Ibn Khaldun's Philosophycal sciences' list and the last three are acquired without the traditional stamp, so we cannot place them in any of the classifications of Ibn Khaldun.

The biggest gap between Ibn Tufayl and Ibn Khaldun can be identified in the non-existence of any notion of 'așabiyya that made Ibn Khaldun's theory whole. Actually, the only place where we could hope to find 'așabiyya in Ibn Tufayl's book is in the civilized society on the inhabited island, but such a limited space in the book was given to that other island that we can only speculate on what kind of social forms are in place there. We can only be certain that religion plays the major cohesive role, which is not the case with Khaldun's theory, in which religion acts as a support for the stability of 'așabiyya. Another civilizational analysis of the civilized society will be given in comparison with our second scholar's theory of civilizations.

Arnold J. Toynbee was a scholar who worked and wrote at a much later time than Ibn Tufayl and Ibn Khaldun. Actually, Toynbee was influenced by Ibn Khaldun, as he himself mentions it in his colossal A Study of History, and was certainly aware of Ibn Tufayl and read his Hayy Ibn Yaqzan. Toynbee's theory of civilization was one of the most famous and most influential at the time of its publication in mid- $20^{\text {th }}$ century. When comparing his theory of genesis, growth, breakdown and dissolution of civilizations with Ibn Tufayl's Hayy Ibn Yaqzan, one cannot deny the connections which can be drawn between the two studies, even though their subjects are different. One of the most laudable things about Toynbee's methodology was that he strove to overcome the national historical model and to view history and its intelligible unit as part of a "bigger picture". The same can be said about Ibn Tufayl, who through his hero Ibn Yaqzan moved from the tiniest elements of Earth to the celestial bodies in order to obtain the "bigger picture" in which he eventually found the reflection of himself. 
According to Toynbee, the main cause for the beginning of the civilizing process was a push that changed the human state from stagnation to action and thus started the civilizing process. Toynbee found this cause in the flux of challenge and response. However, Ibn Tufayl finds Motion everywhere and sees it as an Attribute of the Body. The main cause of Motion is the move of God who created everything. He is the main source of the cause and the effect. Through the notion of the source of everything Ibn Tufayl implies the connection of all the Essences to the One Essence through which entire Mankind is interconnected. It is this very unity of Mankind that is the main goal of the civilization, according to Toynbee, who says: "the goal of civilization is creating a state of society in which the whole of the Mankind will be able to live together in harmony, as members of a single all-inclusive family" (Toynbee 1972: 44). And this unity will preferably be obtained through a single all-unifying religion. Ibn Tufayl's Essence is the only entity capable of understanding God and by that faculty it can be compared with Toynbee's Subconscion which enjoys the same effortless harmony with God as a non-human creature. Following this line of analysis, we will find that Toynbee's Universal church has the same goals as Ibn Tufayl's Union with God, and that is obeying his Will (Ibn Tufail 1929: 125; Toynbee 1974: II/105). Obeying the Will of the Agent of infinite Perfection (Ibn Tufail 1929: 107) will serve as an infinite source of creative powers that will, according to Toynbee, secure the infinite existence of a civilization.

By employing the notion of creative powers we will gradually depart from the sphere of the higher mysteries, where we found many similarities between the two scholars, and we will move toward the human society, where other similarities exist. Like a Body which, once abandoned by its soul, starts to disintegrate (Ibid: 63), so does a society when it irrevocably loses its creative powers which radiated from the creative minority or an individual. This creative minority or an individual can be observed in Ibn Tufayl's work in the characters of Absal, the selected few who were chosen by Absal to be introduced to the higher mysteries by Hayy, and even to Hayy himself. Furthermore, we can analyze the entire civilized society from Hayy Ibn Yaqzan through the prism of Toynbee's theory and our interpretation would not be out of place.

The two main actors in the civilized society are Absal and Salaman (salāmān). They pertain to the same religion but Absal chooses, in the sense of mysticism, to withdraw himself so that he can find a positive response to the challenge their society is facing. Salaman is literally observing the religion and is the king of the society. He can be seen as a dominant individual (a minority) who was overtaken by the new religion and is now forcing it on the rest of the subjects (Ibid: 156) who assume the role of the proletariat, 
which is at one point in the story referred to as the Vulgars. Through this explanation and the negative stance that Ibn Tufayl has towards the society (Ibid: 160,164, 166) we can conclude that this society is experiencing its breakdown or a period of dissolution. Absal returns to the society with the response for their challenge in the form of Hayy who would teach them the way to the Truth. However, Absal's response proves unsuccessful since the proletariat refuses to mimic the new creative power. Reasons for this reaction can be either too strong a connection between the dominant minority and the proletariat (here we could perhaps introduce the notion of Ibn Khaldun's 'așabiyya, if we had more material), or the impossibility to reach the Truth by just mimesis. To gain the Vision, the proletariat must experience the change that constitutes, according to Toynbee, the perfect response, but it rarely happens. In the end, Hayy and Absal decide to return to the isolation with the conclusion that not all people can gain the Vision and that this religion made of symbols completely agrees with the people.

At this point we would also like to mention some similarities we find in the field of learning and which we did not cover when relating to Ibn Khaldun, but which can be discussed in association with Toynbee's theory. We mentioned all the types of intellect that are present in Ibn Tufayl's work, but if we add Toynbee's challenge and response aspect, we could get a clearer picture of the process. Intellects are developed gradually and the main impulses for their development are received from the environment. These impulses from the environment can be interpreted as responses to challenges, as was the case with Hayy when he was collecting food, making clothes and providing shelter for himself. When he mastered the knowledge of Nature (Ibid: 70), these impulses shifted to another sphere, an internal one, and the process which Toynbee calls etherialization started. It is through etherialization that a true growth is achieved and this is where Ibn Tufayl unintentionally meets Toynbee again, since through etherialization Hayy Ibn Yaqzan reached the real Truth. Considering that by achieving etherialization creative powers are renewed, etherialization could sustain a civilization indefinitely, but failing to experience etherializations leads to the creation of a dominant majority, which is one of the signs of the breakdown of civilization. Similarly, Ibn Tufayl suggests that without reaching the real Truth or oneness with the One and remaining in His presence a person cannot achieve a Heaven on Earth and will be destined to suffer one of the first two types of death that will be discussed at a later point in the article.

We can perhaps add one last thing in connection with Toynbee before we move on to the next aspect of Ibn Tufayl's civilization theory, and that is Ibn Yaqzan's place in a society. We already mentioned his reaction to the human society, but that is not the only society that Hayy was a part of. Animal society 
was not what Toynbee had in mind when he said that "society is the total network of relations between human beings. Not human beings, but relations between them" (Toynbee 1972: 43). Still, the Herd of Deer that Hayy Ibn Yaqzan was a part of, thanks to the abilities of a story, is much more similar to human society as its members live together, provide shelter and food for the group, and it even has its own voices in which it communicates: "so the Boy being always amongst them learn'd their voice by degrees $[. .$.$] and could express himself as$ they do, either when they want help, call their Mates, when they would have them come nearer, or go farther off" (Ibn Tufail 1929: 52). Primitive as it may be, even with these supernatural abilities that were bestowed upon it by the story, still this animal society gave some sense of group feeling to the young Hayy Ibn Yaqzan and prepared him for the "Condition of Mankind [ahwāl $a l-n \bar{a} s][\ldots]$ that the greatest part of them were like Brute Beasts" (Ibid: 175).

The majority of the elements of the civilizational process that could be found in Ibn Tufayl's philosophical treatise were already counted for in correspondence with the elements of Ibn Khaldun's and Toynbee's civilizational theories. Still, there remains a corpus of elements that could not be compared and can be deemed uniquely Ibn Tufayl's. These elements are certainly in the closest connection with the mystical and even sufistic tendencies of Ibn Tufayl, but even if it is so, they can give us some notion of the civilization process, especially for a person like Hayy Ibn Yaqzan.

The first thing that attracted our attention was the three actions needed in order for a person to obtain the Vision of the other World or the self-existent Being. As we mentioned earlier when we were discussing the World of Generation and Corruption, only a balance of the opposing elements can keep the World from corruption. In a similar way, only a balance among the Body, the Spirit and the Essence can enable a person to obtain the Vision. The first of these actions is regulating the Body. As the lowest of all the entities, the Body should be sustained only as much as it is needed for the Spirit to stay alive. The only thing Body needs is a limited quantity of food and protection in the form of shelter (Ibid: 128-129). The purpose is to keep the Body as basic as possible, without any riches and luxuries that could corrupt it. The second action is concentrated on the relationship with others, self and the Creator and it represents the Spirit. Here we can observe the core of the civilizing process of Ibn Tufayl as it would regulate the relations in a society if there was one. The relationship with others is represented in helping others and removing the possible defects from the World (Ibid: 133-134). The second relation is concentrated on the self and concerns keeping the body clean, washing oneself and doing the circular motions like those "around his House or some Stone" (Ibid: 135). The third relation that is dedicated to the Creator consists of "confining his Thoughts to the Contemplation of that 
necessarily self-existent Being" and, also, "rapidly turning himself round, in which when he was very violently exercis'd, all manner of sensible Objects vanish'd out of his sight" (Ibid: 135). These relations are formed in such a way so that they substitute or reaffirm the religious rituals of Islam like circumambulation, dhikr, abolution, etc. However, in the work of Ibn Tufayl they were inspired mostly by the imitations of the spheres or the planets. At the end of the second action the Vision is obtained. Before performing the third action, the first two must be repeated in cycles in order to obtain a perfect balance. Only when the perfect balance is achieved, can the third action the union with God - take place. During this action the Body, the Spirit and the Essence are denied until all is lost and only the One True Being remains. Again, the purpose of the civilizing process is the unity and oneness of the humanity in the One Being.

An interesting notion of what Ibn Tufayl propagates can be found in his description of the death of the Body. Here we can also find three possible outcomes. The first is the person who never used his Essence and by not doing so never understood the Creator. His life was based on the corporal faculties and when it dies, with it also dies the desire of that soul. These souls have no troubles and feel no pain, but are in the same condition as the animals because they are all deprived of reason (Ibid: 115). The second person used the faculty of the Essence and acquired the notion of the Being, but turned away from him and continued his corporal life until death. This person will be deprived of the Vision in the afterlife but will have the desire to join it. This will bring him pain and misery. These souls will be judged and can be acquitted after which they will be allowed to return into the Presence. The third person is the one who obtained the Vision and never abandoned it. He constantly remains in the Presence and when death comes he will just continue to be "in everlasting Pleasure and Delight" (Ibid: 116). This clarification of the notion of afterlife is important for the formation of Ibn Tufayl's civilization theory since it reaffirms the importance of reaching the goal of civilization. If unity is reached during lifetime, even death will be negated and it will establish a Heaven on Earth.

\section{Conclusion}

"Time in its irresistible and ceaseless flow carries along on its flood all created things, and drowns them in the depths of obscurity..." Anna Comnena, Alexiad

In the conclusion of our paper we will try to make a logical and coherent overview of the previously examined theory of civilization by $\mathrm{Ibn} \mathrm{Tu}$ fayl. We will try to exclude the possible exaggerations, oversimplifications, 
inconsistencies and weak argumentation in order to get a purified and usable theory. We are aware that the possibilities for that are far fewer than the impossibilities, as there is no perfect theory of civilization - yet - that is able to satisfy all the aspects of such a complex topic like the question of civilization. So we will be satisfied if we succeed in producing an initial form, a first draft that will push someone else to undertake such a complex and arduous endeavor.

Ibn Tufayl's civilization theory has several specific aspects which are not that common among the theories of civilization. Nevertheless, it represents a process that starts at the basis and leads upwards to the domain of the higher knowledge or mystery. At the basis of Ibn Tufayl's theory is the material world, represented in the term of Body. This Body exists in the World of Generation and Corruption, which implies a circular and deterministic process. Yet, the World of Generation and Corruption cannot be completely annihilated, just changed. Corruption in the way of change comes to pass if the Body loses its balance of the opposing elements. This imbalance is most easily seen in the accumulation of the material things such as possessions, money and luxury. These opposing elements are kept in balance by the work of the Spirit located in the Heart of every Animal (including human beings).

This Spirit has the function of the Mind that incorporates through different faculties all the intellects. The Spirit, through its intellects, is used for acquiring knowledge by which the World starts being perceived. This accumulated knowledge leads to the conceiving of a religion that has a central part in Ibn Tufayl's theory, even though it is not necessarily a formal religion as much as it is a form of spirituality. Nevertheless, this spirituality is not in contradiction with a formal religion, it is rather a form of formal religion that is deprived of its symbols and metaphors. This religion represents the core of the civilizing process of Ibn Tufayl as it regulates all social aspects of a human being. Through religion a person has an obligation to sustain his body, to care for others, to take care of personal hygiene and worship his Creator. Sustaining the body is limited to a bare minimum of needs in order not to upset the balance of the Body and the Spirit.

One of the curiosities of Ibn Tufayl's civilizational theory is that it essentially does not need a society and it is greatly centered on an individual. As we can see in the book, Hayy Ibn Yaqzan entered the civilizing process without being a part of any society (if we exclude the animal society). However, the rules for the formation of a society are inherent in religion. Despite the great importance that religion has in this theory, it is not the goal of the civilizing process, but just a means. The goal of civilization, according to Ibn Tufayl, is to acquire the knowledge of the Essence that will lead the person further away from the simple observance of the religious rituals and 
bring him directly to the presence of God. With the Essence, Ibn Tufayl completes his tripartite definition of the existence of every human being which is a union of the Body, the Spirit and the Essence. While all three part are constantly present in a human being, only by acquiring knowledge, i.e. by employing the Spirit, can one become aware of his tripartite self and keep it in balance. Only then can one come into the Presence, the Presence that will prove so captivating that it will entice the person to deprive himself of the Body, the Spirit and the Essence and unite completely with One, in One. By this union people would fulfill their civilizing purpose and unite in a harmonious Mankind.

This would be Ibn Tufayl's theory of civilization in a brief overview that relies on the most explicit and clearest of the elements that could be extracted from his book. Anyhow, there are much more elements that could be analyzed, interpreted, understood, allocated and contrasted, but with how much certainty we cannot say. This short analysis is delineated by the book whose limits we cannot and should not overstep. Many questions remain unanswered, like: How does a generational change happen? How is the power organized inside a society? And what constitutes the culture of a society? Just to mention some of them. Without clear answers to these questions, we can consider this theory to represent only fragments of the complete one. For a real theory of civilizations by Ibn Tufayl we should find one in reality or in a more detailed story. Nevertheless, the analyses provided in this work show that Ibn Tufayl not only elaborated on his philosophical standing in his Hayy ibn Yaqzan, but also provided clear pointers to the civilizational formation of individuals along the way. Perhaps this focus on an individual in a civilizational process should be the starting point of reexamination of the existing civilization theories.

Received: June $16^{\text {th }}, 2017$.

Accepted: July 24, 2017.

\section{Bibliography}

Alatas, Syed Farid (2012), Makers of Islamic Civilization: Ibn Khaldun, London, Oxford UP.

Amīn, Ahmad (2005), Hayy Ibn Yaqzān li Ibn Sinā wa Ibn Ṭfayl wa al-Suhrawardī, Dimashq, Dār al-madā liltaqāfa wa al-nashr.

Fulton, A. S. (1929), "Introduction”, in Ibn Tufail, Abu Bakr, The History of Hayy ibn Yaqzan, translated by Simon Ockley, London, Chapman and Hall, 5-37.

Goodman, Lenn (2000), "Ibn Tufayl”, in Menocal, Scheindlin and Sells (ed.), The Literature of Al-Andalus, Cambridge UP: 318-330. 
Toynbee, A.J. (1972), A Study of History, ed. Caplan, Jane, Oxford University Press, London.

Toynbee, A.J. (1974), A Study of History, ed. D.C. Somervell, D.C, Oxford University Press, London.

Ibn Tufail, Abu Bakr (1929), The History of Hayy Ibn Yaqzan, translated by Simon Ockley, London, Chapman and Hall. 